\title{
GETTING STARTED WITH INCREMENTS AND TRANSFORMATIONS
}

Dr. Kingsley A. Reeves Jr., Assistant Professor, Department of Industrial and Management Systems (IMSE), College of Engineering at the University of South Florida, had just completed the first four days of a five day workshop - the "Institute for Increments and Transformations" (a.k.a., the institute) offered by the University of South Florida's (USF) Center for $21^{\text {st }}$ Century Teaching Excellence (C $\left.{ }^{21} \mathrm{TE}\right)$. During those four days he had been exposed to a variety of presentations and case studies relating to teaching innovations, and had participated in training in a number of technologies. But now, for the final day, he was going to be experiencing something entirely different. His own class, EIN 4933/5322 (Principles of Engineering Management), was to be the subject of the final case to be discussed.

The key objective of the class, taught by Reeves for the first time in spring 2005, was to teach management techniques to engineering students. The course was also offered through the Florida Engineering Education Delivery System (FEEDS). This meant it had to be designed with two student populations in mind: those who took the course in a traditional classroom setting and individualsthroughout the state of Florida - who would be viewing recorded versions of the class. The purpose of the case study written about his class was to promote discussion of ways in which the course could be enhanced through using technology and innovative teaching techniques. While the case was being written, Reeves had prepared himself by looking over some of the other cases that had been written for the institute-cases covering a broad range of topics such as developing and using multimedia content, online discussion techniques, increasing classroom interactions with audience response units and, perhaps most significantly, the challenges faced by faculty members while trying to manage technology implementations and complex course designs. While immediately recognizing the potential relevance of many of the techniques presented to his particular course, these cases had also emphasized the many pitfalls that accompanied changes to course design. Driven by his love of teaching, Reeves was naturally

\footnotetext{
This case was prepared for the purpose of class discussion, and not to illustrate the effective or ineffective handling of an administrative or classroom situation and is copyrighted by the Informing Science Institute. Permission to make digital or paper copy of part or all of these works for personal or classroom use is granted without fee provided that the copies are not made or distributed for profit or commercial advantage AND that copies 1) bear this notice in full and 2) give the full citation on the first page. It is permissible to abstract these works so long as credit is given. To copy in all other cases or to republish or to post on a server or to redistribute to lists requires specific permission and payment of a fee. Contact Publisher@InformingScience.org to request redistribution permission.
} attracted to those innovations that would transform his course. On the other hand, as an untenured Assistant Professor completing his first semester at USF, was it really wise to initiate such challenging (and, doubtless, time consuming) changes? Or would more modest incremental changes, opening up more time for research and grant writing (the bread and butter of the College of Engineering), be a better fit with his present stage of life? 


\section{USF Department of Industrial and Management Systems (IMSE)}

The IMSE Department was one of six in USF's College of Engineering (CoE), established in 1964. Although the number of CoE students (2321 undergraduate, 805 graduate) and faculty (96, with an additional 44 research faculty) made CoE small relative to many of USF's other colleges, the CoE had been an important contributor to USF's rise to Research I status in the 1990s. In particular, its faculty had been responsible for a disproportionately large quantity of the grant dollars that flowed into USF. Indeed, outside of USF's medical school, few USF colleges—regardless of size-could top CoE's \$22 million grant production for 2004. (Source: CoE Annual Report at http://www2.eng.usf.edu/Documents/USFCOEAnnualResearchReport.pdf accessed on 5/28/2005, University of South Florida Research Fact Sheet at http://www.research.usf.edu/vpfr/FactSheetFinal.pdf accessed on 5/28/2005)

Within the CoE, the IMSE department's 13 faculty members made it relatively typical in size. The department was inherently cross-disciplinary in focus - since effectiveness in areas such as manufacturing required attention to both engineering and business details. According to the CoE's Annual Report, IMSE's principal research thrusts included: advanced materials research, education research, healthcare and humanitarian research, manufacturing processes research, and transportation and logistics-related research. The second of these areas, education research, was rather unusual for an engineering department and was underscored by the emphasis placed on students in the Chair's message on the departmental web site (Exhibit 1). Furthermore, IMSE had been very successful in acquiring outside funding for a number of its education projects, and the area was prominently featured in the CoE Annual Report (Exhibit 2).

\section{Dr. Kingsley A. Reeves Jr.}

As summarized in Exhibit 3, Dr. Kingsley Reeves Jr. had a relatively unusual background for someone in the engineering field. As he described it:

Most faculty members in my position have followed a straight trajectory-from undergraduate to masters to $\mathrm{PhD}$ with no breaks in between. I, on the other hand, come to this position with a lot of work experience-six years working at Ford Motor Co. and three as a consultant with PricewaterhouseCoopers. Even when I was going to graduate school, I wasn't entirely sure whether I wanted to go into the technology or management side of industry. For that reason, I got both an MBA and a Master's in Industrial Engineering.

By 1998, Reeves had completed both of his Master's degrees at the University of Michigan, Ann Arborwidely regarded as one of the top public universities in the country. He continued in industry, as a consultant, for the next three years but was intrigued by the notion of going on for a doctorate. Continuing his description, he confessed:

Although I probably shouldn't admit this, I recall making the decision while I was doodling on a sheet of paper and wrote out "Dr. Kingsley A. Reeves, Jr.". Looks good, I thought to myself. And, since my GRE was about to expire, I decided that now was the time.

At the time when he enrolled in the University of Michigan's doctoral program, Reeves' thoughts were to complete the degree then return to industry or consulting, both of which valued doctorates in engineering. This plan remained in place for about a year. Then, as a requirement of his fellowship, Reeves began teaching during his second year. Almost instantly, his career plan changed. Whatever course he would chart for his career, Reeves knew it would have to involve teaching. 
Reeves joined USF's IMSE department in January 2005, as a tenure track Assistant Professor. As he looked out over the five years to come, he saw himself developing three distinct areas of focus for his own research:

- Discovery research, the "traditional" research focus of engineering, with a heavy emphasis on publications, grants and patents. His particular area of interest was in supply chain research and multi-firm collaboration - a popular research topic in both engineering and business.

- Scholarship of teaching, treating the teaching of engineering as a valid research area in its own right.

- Industry-driven research and consulting, building on his existing background and skills in working with businesses.

Of course, where to find the time to work in all three areas was still a matter to be resolved. The problem would be particularly acute, Reeves noted ruefully, if he were to be given more courses like EIN 4933/5322.

\section{EIN 4933/5322: Principles of Engineering Management}

When Reeves arrived at USF, his first teaching assignment was EIN 4933/5322, a course intended to introduce managerial concepts to engineering students. The course was offered to both undergraduate students and graduate students and, for many, was their first exposure to managerial approaches to issues such as leadership, team building, and problem solving. Sections of the course tended to consist of about 50 students, with roughly equal numbers of graduate and undergraduates.

The course, as it was offered at USF, was challenging to teach for two reasons. The first was a result of the material itself - which involved attempting to get students to try out a totally different perspective. For example, when confronted with a complex manufacturing system to implement, an engineering student would naturally tend to gravitate towards the technical issues of the system-power consumption, appropriate operating conditions, system specifications versus requirements, compatibility with other systems, and so forth. The managerial perspective, on the other hand, might emphasize an entirely different set of concerns - such as return on investment compared to the corporate cost of capital, implications for the labor force (e.g., does the union oppose it?), potential for generating interdepartmental turf wars (e.g., would it shift power from production to marketing if sales people could enter orders directly into the system?), impact on vendor and supplier relationships, etc.

To address this first challenge, Reeves had chosen to make extensive use of the case method-common in business schools but much less common in engineering programs. He felt the case method was a good fit with his objectives for a number of reasons. To begin with, the approach closely resembled the pedagogy used to teach many of the courses in his MBA program, at the University of Michigan. That made him comfortable with the approach and its pedagogical devices. Another advantage was precisely that it was unfamiliar to many of his students. Creating a contrast in pedagogies, he felt, would help students to recognize that the course would require a different mindset than the traditional engineering course. Finally, many of the topics to be discussed in the course-such as how to make a difficult tradeoff between competing technologies - tended to be situation specific, with abstract theory being less important than the ability to ferret out relevant details. This type of content, he felt, did not lend itself to lecturing. Indeed, Reeves tried to limit lecture time to no more than 45 minutes per 3 hour class. 
The second aspect of the course that made it a challenge was the fact that it was concurrently taught in the classroom and offered through the Florida Engineering Education Delivery System (FEEDS). The FEEDS program, established in 1983 by a act of the Florida legislature, was designed to allow students at remote locations in Florida to complete engineering degrees by taking courses from the universities in the Florida state system, including Florida Atlantic University, Florida International University, University of Central Florida, University of Florida, Florida A\&M University, Florida State University and University of South Florida. Over its history, FEEDS courses had been delivered in a variety of ways, ranging from hand-delivered VHS tapes to Internet broadcasts. What magnified the difficulty of teaching a FEEDS course, when compared with a typical distance learning course, was the fact that content generated in the classroom often went out-largely unmodified - to FEEDS sites. That meant students at a remote site might, for example, watch a discussion instead of participating in it. Some attempt to address these issues was made by having discussion leaders available at FEEDS sites when the content was broadcast. But, as the course instructor, Reeves had little control over how classes at the remote sites were conducted-and about half his students were taking the course through FEEDS.

During spring 2005-his first semester teaching the course-Reeves instituted a course design that he felt would help to overcome the challenges he faced. As shown in the course syllabus (Exhibit 4), he incorporated a variety of elements in the design — weekly case discussions, lectures, group projects and exams - so as to avoid over reliance on any one technique. He also put the heaviest weight ( $40 \%$ of the course grade) on a group project. Placing such a value on group activities seemed appropriate, in his opinion, because engineering programs frequently emphasize individual work, while most activities in the business context take place in a team setting. He also developed parallel requirements for classroom and FEEDS students-providing each subset with an opportunity to get credit for participation (up to 15\% of their total grade) in a manner consistent with the class setting. For his classroom students, participation was principally derived from case discussions, with Reeves reserving the right to "cold call" students (i.e., call on them without waiting for them to volunteer) as a means of ensuring adequate preparation. For his FEEDS students, on the other hand, participation was based on student postings to an asynchronous discussion of each case, conducted using the Blackboard course management system supplied by USF. Although not as stimulating, perhaps, as their classroom discussion counterparts, online discussions afforded him the opportunity to gauge the individual contributions of these remote students.

As the semester progressed, Reeves found himself wishing he could get a clearer sense of what was working (and not working) in his course design. At about that time, he became aware of a program offered by USF's Center for $21^{\text {st }}$ Century Teaching Excellence (C21TE) known as the small group instructional diagnosis (SGID). By volunteering for an SGID assessment, he could get a representative of C21TE to visit his class and interview students to get their assessment of how the class was going. He perceived the option as entailing virtually no risk to himself-since results were treated as confidential and were provided only to the instructor-so he decided to volunteer.

In early March 2005, Dr. Diane Williams - the director of the C21TE and an expert in learning theoryhad visited Reeve's class and had contacted his FEEDS students for their insights. The results, summarized in Exhibit 5, had been highly complementary overall. Even so, Reeves had been surprised by some of the comments - such as one from a FEEDS student who seemed to doubt that anyone was reading the Blackboard case discussions. (Since Reeves had spent hours each week poring over those discussions, that comment really stung.) But, in total, he felt quite pleased or, to be more precise, relieved-since the SGID results were the first source of feedback he had received from the FEEDS students. 


\section{Institute for Increments and Transformations}

After having conducted the SGID exercise on Reeves' course, Dr. Williams had strongly encouraged Reeves to consider participating in the summer 2005 institute workshop so that he could further develop his already formidable teaching skills and (somewhat selfishly) so that he could share his techniques and experiences with the other faculty participants of the institute. After Reeves had expressed interest in doing so, she had then proposed another activity: volunteering to be a site for one of the case studies to be discussed during the workshop. Thus it came to pass that, within two weeks of the end of his first semester at USF, Reeves found himself speaking to a case writer (at some length) who had come to ask him questions about his course, his background and his aspirations.

In looking over the spring semester, the case writer had asked Reeves to identify three areas where he thought the course might be improved. Roughly in order of priority, Reeves had volunteered the following list:

1. Increase the level of interaction with his FEEDS students

2. Find ways to make the lecture portion of classes more engaging to students

3. Develop better ways of assessing how much students had learned from the course

Many of the tools that had been discussed in the institute seemed as if they might be useful in meeting these objectives. As part of his obligation to the institute, he was going to need to introduce technologysupported changes to at least one element of his course, then communicate the results of his innovation to others in his department (or elsewhere at USF). That meant he has to decide what challenge was best addressed first. Or, perhaps, should he consider initiating more than one innovation during the fall semester?

He also found himself wondering if he had even identified the most appropriate objectives. Perhaps he should consider an entirely different approach. He knew of at least one National Science Foundation (NSF) grant solicitation that dealt directly with teaching students in engineering. Perhaps he should focus his efforts on preparing a proposal for that grant. But would that type of activity even fulfill his institute requirements?

Finally, of course, there was the question of priorities. While teaching was his passion, he was aware that — at a research university - it was nearly impossible for a faculty member to get promoted purely on the basis of teaching. Furthermore, even though his department had a track record of being very supportive of research into teaching, it was hard to imagine achieving tenure purely on the basis of such research. Maybe the most sensible thing was for him to undertake the smallest "increment" possible, and leave "transformations" for later in his career. But would doing the bare minimum satisfy him? It never had in the past...

With these thoughts going through his head, he started towards the classroom. Somehow, he had gotten himself talked into sharing all his personal and professional concerns with a group of people who-up to four days ago- - he had never even met. His emotions on the subject were mixed. Part of him was excited about the opportunity to participate in such a unique experience. Another part of him was wondering what he had gotten himself into.

He shook his head and chuckled. That case writer must have been one smooth talking devil to have convinced me to go through with this, he thought. And on that note, he walked into the classroom. 


\section{Exhibit 1: IMSE Message from the Chair}

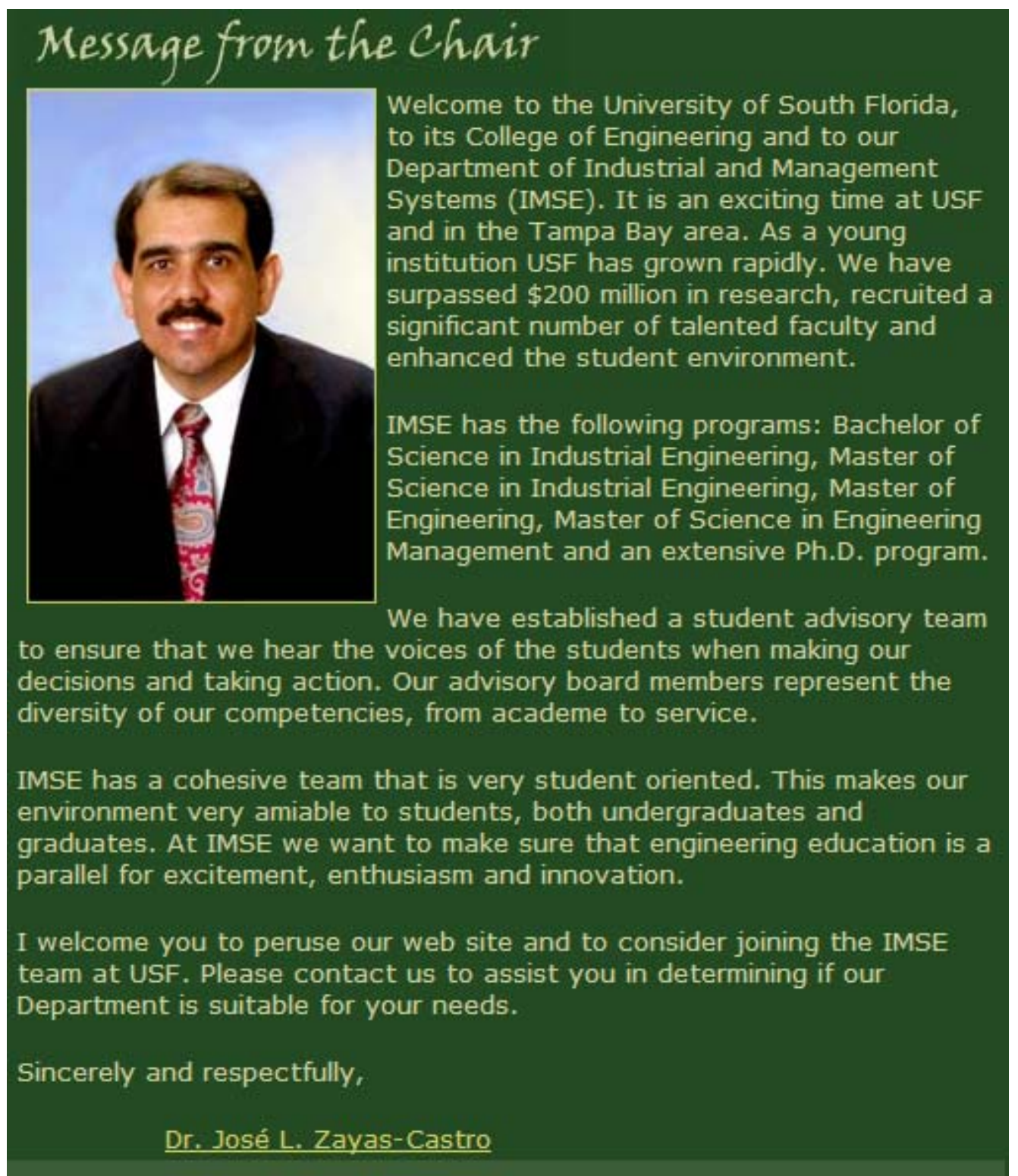

Source: http://imse.eng.usf.edu/fl_0101about_mess.htm accessed on 5/28/2005. 


\section{Exhibit 2: IMSE Education Research}

\section{Education Research}

Accreditation of education programs has undergone a profound change in the past two decades, which can been seen in the shift from providing content to an emphasis on outcomes assessment. Anita Callahan is collaborating with Peter J. Fabri, M.D. and Eric Anderson, M.Ed., to document current graduate medical education practices, such as residency programs, in the U.S.; investigate desired outcomes of residency experiences; study alternative methods of achieving desired outcomes; and provide recommendations for templates that will enable improvements in graduate medical education. Funding: USF College of Medicine.

William Miller is working with Richard Gilbert (Chemical Engineering), Andrew Hoff (Electrical Engineering), and Marilyn Barger, Director of the Hillsborough Community College Manufacturing Technology Program, on the Florida Advance Technology Education Center for Manufacturing Education (FL-ATE). The program, which is a partnership between the College of Engineering, Hillsborough Community College, and St. Petersburg College, seeks to bring together all of the community colleges and technology schools and programs in Florida to develop a curricula and specific education materials to be used in manufacturing and related technology classes and programs. Funding: NSF.

O. G. Okogbaa is working with Department faculty members Tapas K. Das, Grisselle Centeno, and Louis A. Martin-Vega; Ashok Kumar (Mechanical Engineering); and Michael Churton and Brenda Townsend (College of Education) on the Student, Teachers and Resources in the Sciences (STARS GK-12) program, an innovative new program that provides assistance to area grade school teachers. Five elementary schools in the Tampa Bay area are involved and current focus is on K-5 students. The STARS goal is to utilize university-level educational research and information technology to stimulate math, science and engineering interests in pre-college students. Undergraduate and graduate fellows are working in participating schools as resources for teachers, who then learn to utilize the specialized expertise in math, science, and engineering that the STARS fellows provide toward the development of curriculum in these important areas. The program is funded by a \$1.5 million grant from NSF.

José Zayas-Castro is collaborating with department faculty member Dolores Gooding, Gary Havran of the Florida Medical Manufacturers Consortium, and Sally Szydlo, Director of the College's Florida Engineering Education Delivery System (FEEDS) on a project that is looking into re-engineering engineering education. The project seeks to develop a framework that better integrates Just in Time Education, project-based learning, knowledge learning, use of technology, and assessment toward implementing a renewed view of engineering curricula with a primary focus on Industrial Engineering.

(Source: http://www2.eng.usf.edu/Documents/USF-COEAnnualResearchReport.pdf) 


\section{Exhibit 3: Kingsley Reeves Background}

\section{EDUCATION}

UNIVERSITY OF MICHIGAN Ann Arbor, MI

- Rackham School of Graduate Studies Doctor of Philosophy in Industrial \& Operations Engineering, December 2004

- School of Business Administration Master of Business Administration, May 1998

- Rackham School of Graduate Studies Master of Science in Industrial \& Operations Engineering, May 1998

- College of Engineering Bachelor of Science in Electrical Engineering, May 1992

\section{ACADEMIC EXPERIENCE}

UNIVERSITY OF MICHIGAN Ann Arbor, MI

- Graduate Student Research Assistant, 2001-2004

- Graduate Student Mentor, 2003-2004

- Graduate Student Instructor, 2001-2004

WORK EXPERIENCE

- PRICEWATERHOUSECOOPERS, LLP Bloomfield Hills, MI Consultant, 1998-2001

- FORD MOTOR COMPANY Ypsilanti, MI Product Design Engineer, 1994-1998 Manufacturing Engineer, 1992-1994

- UNITED TECHNOLOGIES AUTOMOTIVE Dearborn, MI Consultant, Summer 1997

AWARDS

- Winner, Outstanding Graduate Student Instructor Award, Alpha Pi Mu, University of Michigan Chapter (April 2004)

- Participant, Annual Institute on Teaching and Mentoring, Miami, FL (October 2003)

- Winner, Outstanding Presentation Award, Conference for African-American Researchers in the Mathematical Sciences Graduate Student Poster Session, Purdue University, West Lafayette, IN (June 2003)

- $\quad$ SREB-AGEP Doctoral Scholar (May 2003)

- Michigan Teaching Fellow (May 2003)

- Participant, Rackham-CRLT Seminar on Preparing Future Faculty (May 2003)

- Nominee, Outstanding Graduate Student Instructor Award, ASEE, University of Michigan Chapter (April 2003)

- FOCUS Fellow, Georgia Institute of Technology (January 2003)

\section{RESEARCH INTEREST}

My research interest focuses on the creation of value across the extended supply chain. My research is interdisciplinary in nature and draws upon theory from industrial organization, organizational behavior, and corporate strategy. My emerging research identity is to answer complex problems via a synthesis of multiple research methodologies. I believe that a mixture of quantitative and qualitative methodologies ensures the requisite variety to solve complex supply chain issues. My current research focuses on the firm boundary decision with respect to transportation and logistics within the automotive industry. 


\title{
Exhibit 4: Selected Information from EIN 4933/5322 Syllabus
}

\author{
EIN 4933/5322: Principles of Engineering Management \\ $F$ 3-5:50pm in ENB 113 \\ Spring Term 2005 \\ University of South Florida
}

SYLLABUS

\author{
Instructor \\ Dr. Kingsley A. Reeves, Jr. \\ [Contact information omitted]
}

\section{Course Description}

This course will expose you to the craft of management. There will be an emphasis placed on management practice in an engineering-intensive context. We will cover the fundamentals of management including management theory, planning and control, strategic management, organizing, ethics, leadership, innovation and change, and communication skills. As the term "craft" implies, management is as much about learning in order to do as it is about doing in order to learn. Our focus will be on the former, however, we will expend great effort to provide opportunities for you to practice the craft virtually-primarily via real-world case studies.

\section{Relevance}

The chief executive officer of a corporation, the mayor of a city, the dean of a college, the quarterback of a football team, and a parent all have at least one thing in common: they are all managers. Each of us has myriad opportunities to act as managers and each of us can benefit from learning to manage well. This course will provide you with: 1) a greater awareness of yourself as a manager and 2) knowledge that will enable you to manage more effectively.

\section{Course Objectives}

1. Students will increase their knowledge and understanding of current management theory and practice.

2. Students will enhance their problem solving skills and ability to think analytically.

3. Students will strengthen their general management skills including the ability to plan, organize, control, deal with ambiguity, lead, and communicate effectively.

\section{Course Format and Procedures}

The course will consist of formal lectures, interactive class discussions of assigned reading material (business cases in particular), videos, in-class exercises and guest speakers (as the opportunities present themselves). The intent is to effectively teach the material in a manner that is purposefully redundant, addresses multiple learning styles, and is engaging.

\section{Coursework Feedback and Grading}

A midterm and one individual written assignment will be used to assess understanding of basic knowledge, and a final group project will be used to assess the student's ability to apply concepts to real-world problems within a team environment. Assignments must be submitted by the beginning of class on the day it is due. There will be a one-hour grace period. After the grace period, the final grade on your assignment will be subject to a$5 \%$ penalty. Further penalties will accrue at the rate of $-5 \%$ per day (not to exceed $25 \%$ ). 
The course grade will be determined as follows:

$\begin{array}{ll}\text { Participation: } & 15 \% \\ \text { Individual Mini Paper: } & 15 \% \\ \text { Midterm Exam: } & 30 \% \\ \text { Final Group Project: } & 40 \%\end{array}$

PARTICIPATION: This does not include class attendance. Further, the emphasis is on the quality of contributions, not the quantity. Preparation for class should take around 4-5 hours per week. Study groups are strongly encouraged. Do not come to class unprepared. Important: No marks are subtracted if you say something "wrong". This helps other students clarify their misconceptions. However, if you don't say anything at all, it doesn't help you. If you have something to say, no matter how silly, raise your hand. Class participation is crucial because it helps you build self-confidence. If you want to be an entrepreneur or manager, you must be able to articulate your case convincingly to customers, investors, and others.

The participation grade is based on contributions to class learning and demonstrated ability to answer questions based upon assigned readings. Cold calls will be the norm, and I will generate names for cold calling in a semi-random fashion. You may remove your name from the cold call list by informing me at least one hour before class by email or telephone that you are not prepared (or will not be in class). You may do this at most twice during the semester. If I do not hear from you before class, I will assume that you will be present and fully prepared to answer questions based on the assigned material.

For off-campus students, participation will be based upon participation in discussions on the Blackboard site for the course. I will create forums in the Class Discussions section that focus on a particular case or assigned reading. Sometimes I will generate a question to get you started, but oftentimes will leave it up to you to direct the discussions as you choose.

INDIVIDUAL MINI PAPER: Each student will submit only one short paper on topic(s) of her or his choice selected from readings covered in prior weeks. The paper should not exceed five double-spaced pages in length, excluding tables and figures. More information regarding the mini paper will be available in subsequent weeks.

FINAL GROUP PROJECT: This involves analysis of a case and answering questions that encompass many of the issues discussed throughout the course. In addition to providing an opportunity to reflect on the major topics discussed in the course, this assignment will also permit you to work in a team environment to produce a product.

\section{Pedagogy versus Andragogy}

The term pedagogy is derived from the Greek words paid and agogus, which mean "child" and "leader of," respectively. Thus, pedagogy literally means the art and science of educating children. The term often is used as a synonym for teaching. More accurately, pedagogy embodies teacher-focused education. In the pedagogic model, teachers assume responsibility for making decisions about what will be learned, how it will be learned, and when it will be learned. Teachers direct learning.

Andragogy, initially defined as "the art and science of helping adults learn," has taken on a broader meaning since Malcolm Knowles first re-introduced the term in The Adult Learner. The term currently defines an alternative to pedagogy and refers to learner-focused education for people of all ages. The andragogic model makes the following assumptions about the design of learning: (1) people need to know why they need to learn something, (2) people need to learn experientially, (3) people approach learning as problem-solving, and (4) people learn best when the topic is of immediate value. 
In practical terms, andragogy means that instruction needs to focus more on the process and less on the content being taught. Strategies such as case studies, role playing, simulations, and self-evaluation are most useful. Instructors adopt a role of facilitator or resource rather than lecturer or grader. In this course, we will try to adhere to the adragogic model.

\section{Prerequisites}

No previous knowledge of management related disciplines is assumed. All that is required is a will to work hard and put forth an honest effort. A large portion of the learning that occurs will happen as a result of your preparation outside of the formal classroom. Therefore, it is incumbent upon you to get the most out of the experience.

\section{Course Schedule}

This course will follow the following expected schedule. Guest lecturers may be added if possible to relate course material to industrial applications, so watch the course website for the most up-to-date schedule.

Lectures 1-2: Historical Context

Classical management approaches, behavioral management approaches, quantitative management approaches, continuing management themes

\section{Lecture 3: Information and Decision Making}

Information and the management process, the decision-making process

\section{Lecture 4: Planning and Control}

Short-range and long-range planning, the control process, organizational control systems

\section{Lecture 5: Strategic Management}

The strategic management process, Porter's generic strategies, adaptive strategies, emergent strategy

\section{Lecture 6: Organizing}

Organizational structure, formal versus informal structures, organizing trends and practices

\section{Lectures 7: Entrepreneurship}

Characteristics of entrepreneurs, entrepreneurship in large enterprises

\section{Lecture 8: Ethics}

Ethical behavior, ethical dilemmas at work, corporate social responsibility

\section{Lecture 9-12: Leadership}

Leadership and vision, power and influence, leadership traits, leadership models, motivation, individual behavior and performance, working in teams, group decision-making

\section{Lecture 13: Innovation and Change}

Creativity and innovation, organizational change

Lecture 14: Communications and Interpersonal Skills

The communication process, perception, conflict, negotiation 


\section{Textbook and References}

The course textbooks, available at the bookstore or on amazon.com are:

Bennis, W. G. and Nanus, B., 2003. Leaders: Strategies for Taking Charge. New York, NY: HarperCollins Publisher, Incorporated.

Schermerhorn, J.R., 2005. Management, 8th Edition. New York, NY: John Wiley \& Sons, Incorporated.

There is also a case book for the course (Boston, MA: Harvard Business School Publishing).

Tentative Course Schedule

\begin{tabular}{|c|c|c|c|}
\hline Week & Date & Topic & Before Class Reading \\
\hline 1 & 14-Jan & Introduction & \\
\hline 2 & 21-Jan & Historical Context & $\begin{array}{l}\text { Chapter } 2 \\
\text { Images of Organizations (Handout) } \\
\text { Dee Hock-Visa (Handout) }\end{array}$ \\
\hline 3 & 28-Jan & Information and Decision Making & $\begin{array}{l}\text { Chapter } 7 \\
\text { Tversky and Kahneman (Handout) } \\
\text { Ford Pinto - Gioia (Handout) }\end{array}$ \\
\hline 4 & 4-Feb & Planning and Control & $\begin{array}{l}\text { Chapter } 8 \\
\text { Verizon Case }\end{array}$ \\
\hline 5 & $11-F e b$ & Strategic Management & $\begin{array}{l}\text { Chapter } 9 \\
\text { Apple Computer-2004 Case }\end{array}$ \\
\hline 6 & $18-\mathrm{Feb}$ & Organizing & $\begin{array}{l}\text { Chapter } 10 \\
\text { Eli Lilly Case }\end{array}$ \\
\hline 7 & 25-Feb & Entrepreneurship & $\begin{array}{l}\text { Chapter } 6 \\
\text { Orange Imagineering Case }\end{array}$ \\
\hline 8 & 4-Mar & Ethics & $\begin{array}{l}\text { Chapter } 3 \\
\text { William Lovejoy (Handout) } \\
\text { Paper Due }\end{array}$ \\
\hline 9 & 11-Mar & MIDTERM EXAM & \\
\hline 10 & 18-Mar & SPRING BREAK & \\
\hline 11 & 25-Mar & Leading & $\begin{array}{l}\text { Chapter } 13 \\
\text { Leaders (Foreword - page 79) }\end{array}$ \\
\hline 12 & 1-Apr & Motivation & $\begin{array}{l}\text { Chapter } 14 \\
\text { Leaders (pages 80-140) }\end{array}$ \\
\hline 13 & 8-Apr & $\begin{array}{l}\text { Individual Behavior and } \\
\text { Performance }\end{array}$ & $\begin{array}{l}\text { Chapter } 15 \\
\text { Leaders (page } 141 \text { to end) } \\
\text { Nordstrom Case }\end{array}$ \\
\hline 14 & 15-Apr & Teams and Teamwork & $\begin{array}{l}\text { Chapter } 16 \\
\text { The Overhead Reduction Task Force Case }\end{array}$ \\
\hline 15 & 22-Apr & Innovation and Change & $\begin{array}{l}\text { Chapter } 18 \\
\text { IDEO Product Development Case }\end{array}$ \\
\hline 16 & 29-Apr & $\begin{array}{l}\text { Communication and Interpersonal } \\
\text { Skills }\end{array}$ & $\begin{array}{l}\text { Chapter } 17 \\
\text { Sunk Costs Case } \\
\text { Jensen Shoes Case A/B } \\
\text { Final Group Projects Due }\end{array}$ \\
\hline
\end{tabular}




\section{Exhibit 5: Selected Results from Small Group Instructional Diagnosis}

\section{A. Comments from classroom students}

1. What is going well?

- The class is fun.

- Like the diversity of the case studies.

- Good at spurring interest in the topics.

- Good interaction.

- Makes you feel comfortable with providing input.

- Very P/C - sensitive to people's perspectives

- Good control over the class

o *No arguments break out

- Structure and content well presented

- Cold calls keep students focused.

- Exciting class for a Friday.

- Flexible to students' needs.

- Good job breaking down the three hours.

2. What improvements do you suggest?

- Need more breaks.

o *Not everyone agrees with that; maybe lengthen existing breaks.

- Sometimes discussions of cases run too long/short - need better management.

- Bring in people from industry to interact.

- Field trips to companies.

- Remove "dense” reading from course (Lovejoy)

- Don't make cold calls at beginning of discussion - wait till ideas begin to grow.

- Sometimes too much material chosen.

o * Like today - focus on one or two topics.

- Make slide lectures more interactive.

- Watch digression

o * Some like it.

- $\quad$ Choose more interesting studies (Ford Pinto - good; Heuristics - bad)

- Choose earlier edition text. They are almost exactly the same but a lot cheaper.

3. Comments

- Time has been spent more on case studies so the mid-term should focus on concepts we used when talking about the cases, not the exact name of an idea on the slides.

- One student feels the class is more about learning not about earning a grade, so he is not worried about papers or test grades.

- *You are doing very well for your first semester. We are all enjoying the class. 


\section{B. Comments from FEEDS students}

1. What is going well?

- This course seems, so far, to be going well for me. The instructor, Dr. Reeves, is smart and pleasant, the assigned text hits the points without a lot of run-on, and the case-studies are very informative about "real-world" issues. Thus far, I see no room for improvement.

- I like the reading assignments. They are exposing me to things relevant to engineering that I have never had to think about as an engineer. My favorite readings were Lovejoy's paper on ethical frameworks, the paper on heuristics, and the Ford Pinto Case; but I enjoyed them all.

- Maintaining the interest of the students is a major accomplishment. The venue of the course (3 hours on a Friday afternoon) put the odds against the teacher being able to engage the students and keep them interested, but Dr. Reeves is doing an outstanding job, even when the course material does not necessarily keep you on the edge of your seat.

- I think Dr Reeves is doing a great job, the class is very interesting, dynamic and didactic. He shows good knowledge and background in the areas of discussion.

- The class interaction

2. What improvements do you suggest?

- Sometimes I have a hard time seeing the relationship between the readings and the "lecture" information presented on slides. This is more of a suggestion for me, as a student, than for the instructor. It requires more discipline on my part to follow the lecture slides than it does to study the cases.

- Since this is the first time Dr. Reeves has taught this course, this suggestion could not have been implemented this semester, but a more thorough class-by-class breakdown of the material covered would have been helpful. Maybe in future semesters...

- More interactive videos

\section{Comments}

- This is the last class I am taking for my master's in engineering, yet it is the first management class I have ever had. I am really enjoying the new perspective.

- The class is interesting and the cases are informative. However I believe the reading is a little much. That is the only conflict in this class.

- I am a Webcast student with a very busy travel schedule. Without the Internet option, I would not be able to enroll in this course, so my first comment is to emphasize the importance of offering engineering courses via FEEDS. It's an outstanding capability, and an option that is not available at the other Florida schools to the extent that it is at USF. Kudos!!

- Dr. Reeves does a very good job balancing management theory (which always sounds good on paper) with actual implementation of these theories in the business world. The case studies are quite helpful in this. In my opinion, that's what makes the course both interesting and useful.

- In summary, Dr. Reeves is an outstanding instructor, and is a valuable addition to the USF faculty.

- The only comment that I have is about the discussion boards and the way how they affect your grades. For example in my case, I am actually taking three classes, it means three different discussion boards, between family, job and classes, I don't have enough time to participate, and even when I do, it seems like you are writing something that nobody is going to read. I just think that that percent of grading should be an option, and you should be able to decide if you want to participate of it or not.

- Great job for your first time at U.S.F. 


\section{Biographies}

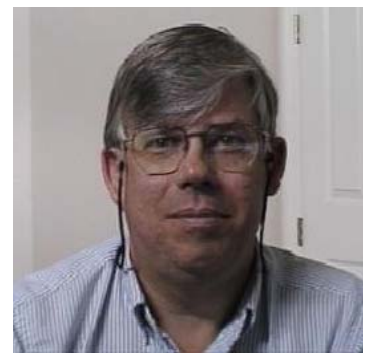

Grandon Gill is an Associate Professor in the Information Systems and Decision Sciences department at the University of South Florida. He holds a doctorate in Management Information Systems from Harvard Business School, where he also received his M.B.A. His principal research focus is in the area of IS education, and he has published many articles describing how technologies and innovative pedagogies can be combined to increase the effectiveness of teaching across a broad range of IS topics. Currently, he teaches programming, database and managerial courses to both undergraduate and graduate students.

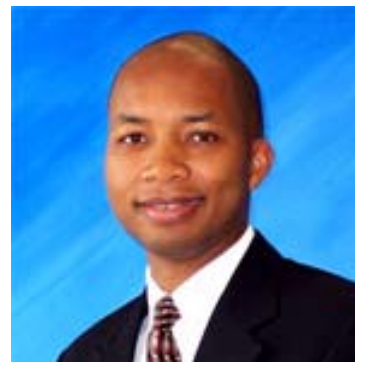

Kingsley Reeves, Jr. is an Assistant Professor in the Department of Industrial and Management Systems at the University of South Florida. He holds a Ph.D. in Industrial and Operations Engineering from the University of Michigan, where he also received a Master's degree and an M.B.A. His research interests include supply chain management, organizational structure, collaborative networks, and managerial decision making in outsourcing. His extensive professional experience includes consulting with PricewaterhouseCoopers, LLP and working as a product design engineer for Ford Motor Company. 